\title{
Road transport energy consumption in the G7 and BRICS: 1973-2010
}

\author{
Yi-Xuan Gao ${ }^{1,2}$, Hua Liao ${ }^{1,2}$, Paul J. Burke ${ }^{3}$, Yi-Ming Wei ${ }^{1,2}$ \\ March 2015 \\ ${ }^{1}$ School of Management and Economics, Beijing Institute of Technology, Beijing 100081, China \\ ${ }^{2}$ Centre for Energy and Environmental Policy Research, Beijing Institute of Technology, Beijing \\ 100081, China \\ 3 Arndt-Corden Department of Economics, Australian National University, Canberra, ACT 0200, \\ Australia
}

\begin{abstract}
Road transport will account for a large share of developing countries' future energy demand. This paper reviews the trends in road transport energy consumption in 12 countries (Group of 7 and BRICS) over the period 1973-2010. We report several stylized facts: road transport energy use and its share in total energy use have been rising; there were large differences in road transport energy use per capita across countries, resulting from differences in country size, resource endowments, fuel prices, and other factors; oil accounts for approximately $95 \%$ of road transport energy in the selected countries (except Brazil); oil will likely be the dominant road transport energy source in most countries for some years to come but not in the long run; and the use of alternative road transport energy sources is increasing.
\end{abstract}

Keywords: Road transport; Energy consumption; Historical 


\section{Introduction}

Transport is a vital sector for any economy and nation. Road transport - the road-based movement of people and freight in and between cities, whether private or public - is one of the most widely used and popular means of transport and is also a key energy consumer. As incomes rise and urbanisation continues, demand for road transport is increasing. Given this, it is important to document the characteristics, patterns, and historical trends of long-term energy consumption for road transport and to compare the experiences of countries at different development levels.

This paper is the first to examine the characteristics of road transport energy demand in the Group of Seven (G7: the United States (US), Canada, the UK, France, Germany, Italy, and Japan) and the five BRICS countries (Brazil, Russia, India, South Africa, and China) by descriptive analysis. These countries are important; in 2010, their gross domestic product (GDP; purchasing power parity (PPP), 2005 constant prices), energy consumption, and road transport energy consumption accounted for 63.9\%, 61.8\%, and $62.1 \%$ of the world's totals respectively.

The data we use are from the International Energy Agency (IEA, 2012), International Road Federation (IRF, 2012), World Bank (2014), and U.S. Energy Information Administration (U.S. EIA, 2012). Energy consumption is calculated using the thermal equivalence method. We focus on the almost four-decade period 1973-2010. Russian data are available from 1990. The data for Germany include both East and West 
Germany.

Our focus is on the energy used to provide road transportation services, which is a "derived demand" (springing from the demand for transport itself). Our data consider only the energy consumed during transportation rather than energy consumed in the construction of transport infrastructure and equipment.

\section{Energy use by the transport sector}

In 2010, the global transport sector consumed 2.4 billion tonnes of energy in oil equivalent terms, which equalled $27.2 \%$ of global final energy consumption (up 4.1 percentage points since 1973) (IEA, 2012). ${ }^{1}$ This makes transport the second-largest energy-consuming sector behind industry.

As seen in Figure 1, the transport share of final energy consumption increased over our period of analysis in all countries in our sample except South Africa. The transport sector accounts for a higher proportion of total final energy consumption in G7 countries than in BRICS countries. IEA statistics on national transport energy use include consumption by road, railway, domestic water-borne, domestic air, and pipeline-based transport activities. International aviation and marine transport are not included in national-level data.

\footnotetext{
1 The data are from the IEA (2012) unless otherwise indicated.
} 
Figure 1 Structural variation in total final energy consumption

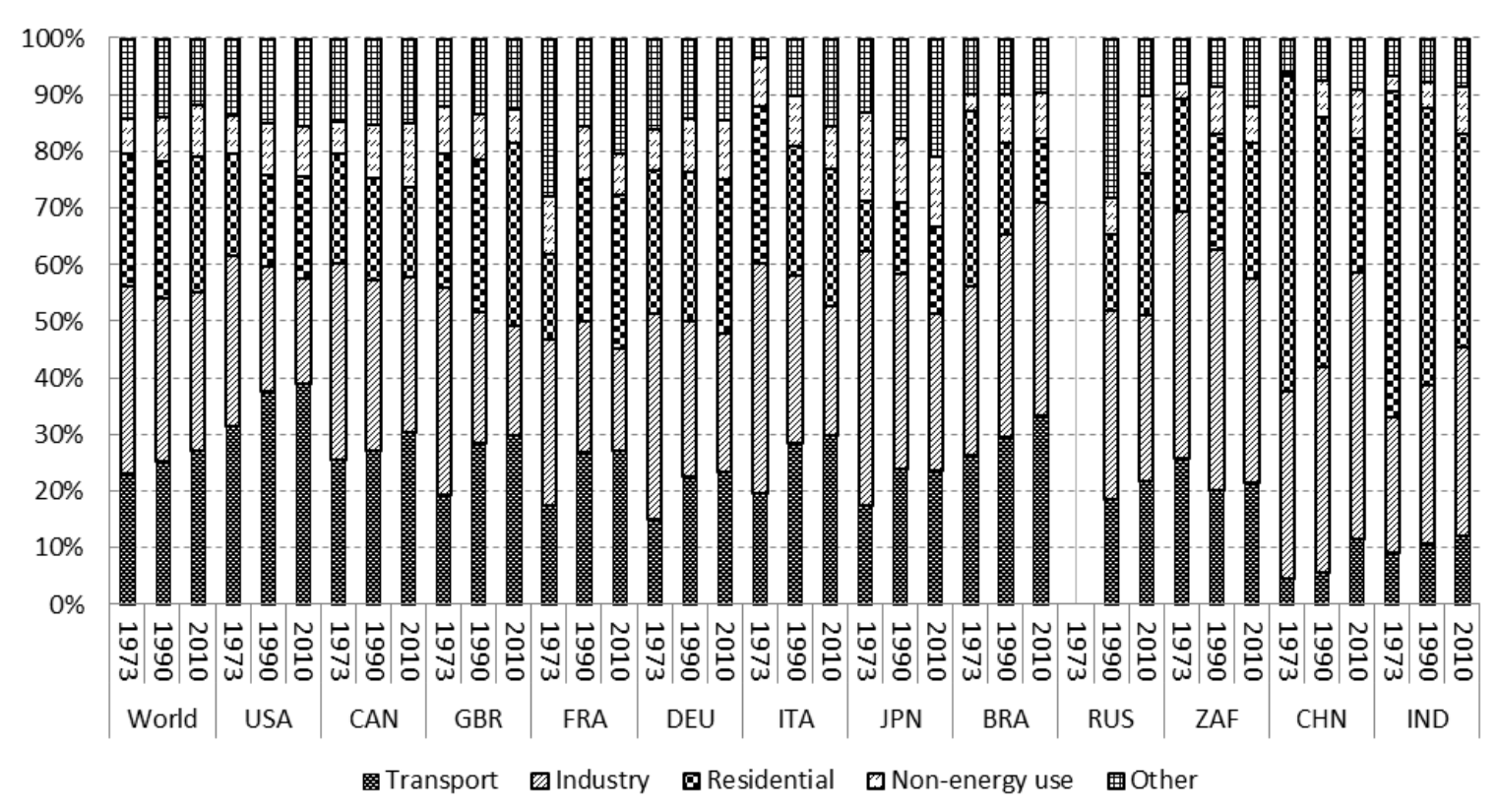

Note: World Bank country abbreviations used throughout. $\mathrm{BRA}=\mathrm{Brazil} ; \mathrm{CAN}=\mathrm{Canada} ; \mathrm{CHN}=$

China; DEU = Germany; FRA = France; GBR = United Kingdom; IND = India; ITA = Italy; JPN =

Japan; RUS = Russia; USA = United States; ZAF = South Africa.

In the G7 countries, industrial energy consumption has levelled off as these countries have moved to more service-based economies and have achieved energy efficiency improvements. At the same time, increasing demand for transport (and more comfortable transport, for example by private vehicles) has seen the amount of energy used in transport increase, despite energy efficiency improvements in transport also. As a result of these two phenomena, the transport share of total final energy use has risen.

In 2010, the US's transport energy consumption reached 580 million tonnes of oil 
equivalent, accounting for $38.9 \%$ of final energy consumption (an increase of 7.4 percentage points from 1973). Canada's transport energy consumption was 60 million tonnes of oil equivalent, equalling $30.4 \%$ of final energy consumption (an increase of 4.8 percentage points since 1973). Transport energy consumption has reached approximately 40 million tonnes of oil equivalent in each of France, Italy, and the UK, nearly $30 \%$ of their final energy consumption (increases of approximately 10 percentage points since 1973). Germany and Japan's year-2010 transport energy consumption was 50 million and 80 million tonnes of oil equivalent, accounting for $23.7 \%$ and $23.4 \%$ of final energy consumption (increases of 8.4 and 6.3 percentage points since 1973). Transport, rather than industry, has become the largest energy-consuming sector in France, Italy, the UK, and the US.

In the BRICS countries, industrial energy use has continued to increase, but transport energy consumption has increased even more rapidly. In China and India, transport remains a relatively small, although growing, contributor to total energy consumption. By 2010 the transport share of final energy consumption reached $11.5 \%$ in China (up from $4.5 \%$ in 1973) and $12.1 \%$ in India (up from 9.2\%). Transport guzzled 170 and 60 million tonnes of oil equivalent in the two countries in 2010, respectively.

Transport-sector energy consumption in Brazil reached 70 million tonnes of oil equivalent in 2010. The transport sector's share of total final energy consumption in Brazil - at 26\% in 1973 and 33\% in 2010 - was higher than in the other BRICS 
countries. This is as a result of factors including Brazil's large land area, relatively low population density, and relatively low residential energy consumption (only $11 \%$ of total energy consumption in 2010).

South Africa is the only country in our sample to have had a declining share of transport in final energy over the period. The proportion of final energy use attributed to the transport sector in South Africa decreased over the period 1973 to 1990, followed by a slight increase from 1990 to 2010 . The reason for this mainly lies in South Africa's complicated history. Due to government policies in the apartheid era, its per capita real GDP showed an overall downward trend over the period from 1972 until the abolition of racial segregation in 1994.

\section{Road transport}

\subsection{Road transport energy consumption versus total transport energy consumption}

Road transport usually makes up the majority of total transport energy consumption, a share that is typically increasing (Figure 2). From 1973 to 2010, global road transport energy consumption rose from 0.7 billion to 1.8 billion tonnes of oil equivalent, an average annual growth rate of $2.6 \%$ per annum. Over the same period, global final energy consumption and GDP grew at average annual rates of $1.7 \%$ and $3.2 \%$ respectively. 
Figure 2 Proportion of road transport energy consumption in total transport energy

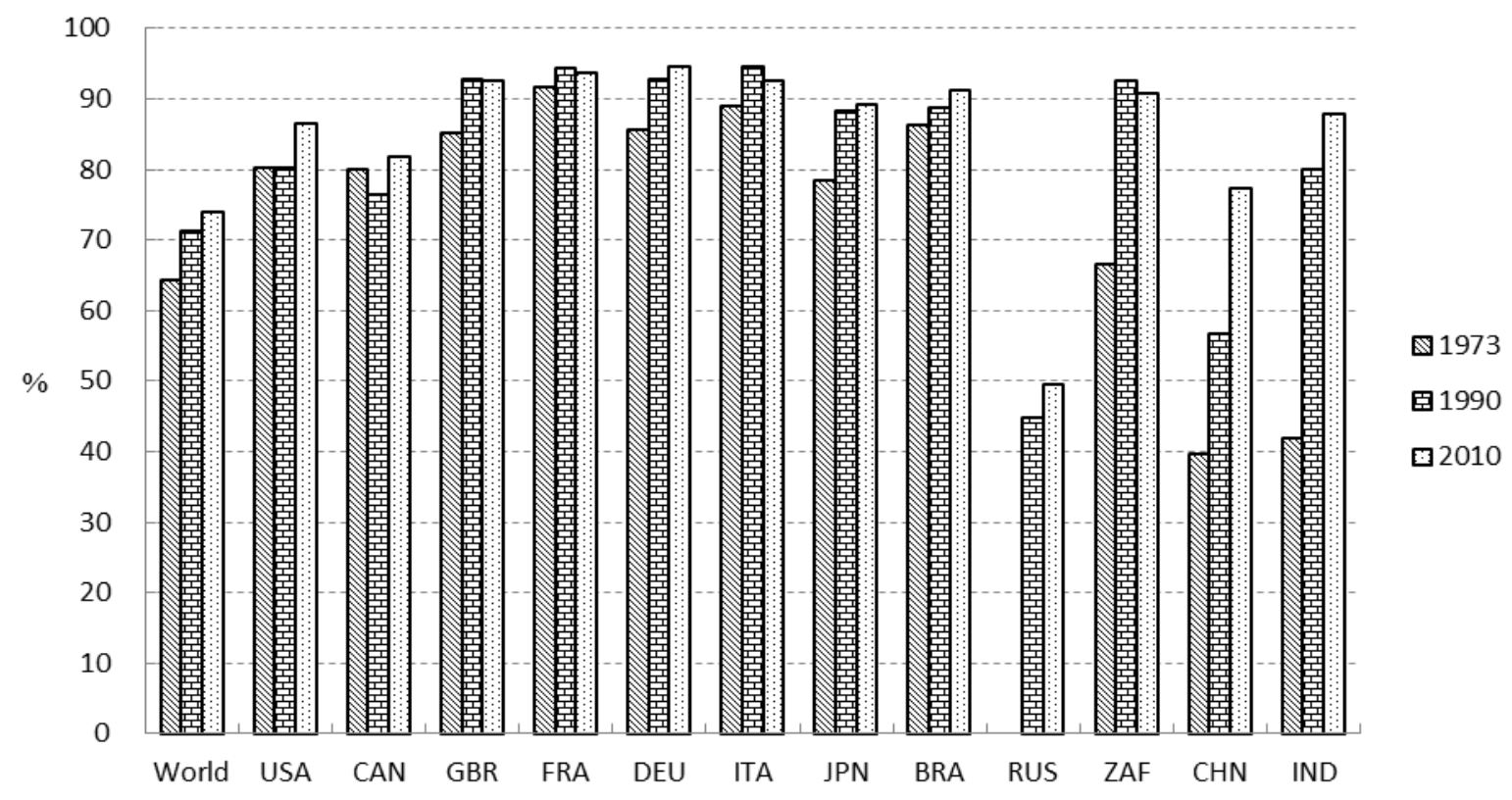

In G7 countries, the share of road transport in domestic transport energy use exceeded $80 \%$ by 2010 , having gradually increased over the last 40 years. Germany is the most road transport energy-dependent ( $94.7 \%$ of transport energy), followed by France at 93.8\%. In both Italy and the UK, the proportions were $92.7 \%$.

From 1973 to 2010, the road share of transport energy use in China, India, and South Africa increased significantly. China and India both doubled their shares (China: from $39.6 \%$ to $77.3 \%$; India: from $42 \%$ to $88 \%$ ). South Africa's road share of transport energy use increased from $66.7 \%$ to $90.8 \%$ over the period. The proportion of rail transport energy use in total transport energy use in these three countries decreased tremendously during this period (China: from $42.3 \%$ to $6.9 \%$; India: from $55.0 \%$ to 6.7\%; South Africa: from $31.4 \%$ to $2.6 \%$ ) as road transport has become increasingly 
dominant. Russia had the lowest proportion of road transport energy consumption (49.6\%) in 2010, up from $44.9 \%$ in 1990 . The reasons for this low share lie in Russia's cold climate (which dissuades some road-based travel) and its widespread use of pipeline-based transport of oil and natural gas (with a transport energy consumption proportion of $36.6 \%)$.

\subsection{National stories on road-transport energy use}

Figure 3 shows that, since 1973, national road transport energy consumption of each country in our sample has increased, but at different rates.

Figure 3 Total road transport energy consumption

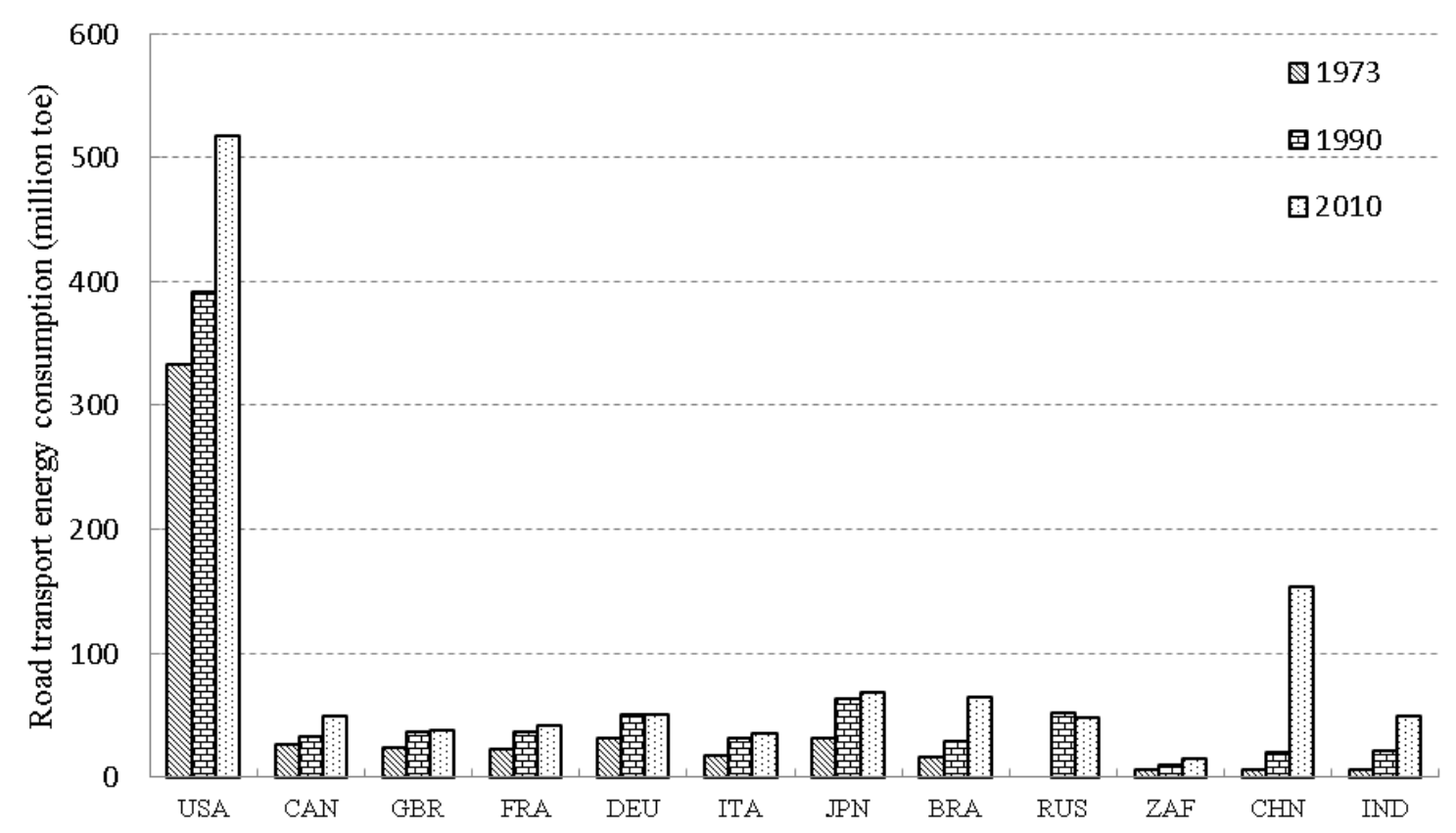

Note: toe is "tonnes of oil equivalent".

Owing to its large land area, large population, high income level, abundant resources, 
and profligate consumption habits, the US consumes far more road transport energy than other countries. In 2010, the total road transport energy consumption of the US was 520 million tonnes of oil equivalent, about 13.7 times that of the UK, 7.5 times that of Japan, and 3.4 times that of China. The US accounts for $28.8 \%$ of global road transport energy consumption; all the other countries in our sample combined account for $34.1 \%$

France, Germany, Italy, the UK, and Japan displayed generally similar road transport energy consumption trends due to their similarities in states of development and geographical conditions. Since 1973, the road transport energy consumption of each of these countries has increased. Over the period 1973 to 1990 , their road transport energy average annual growth rates were about 3\%. In the period since 1990, these average annual growth rates fell to less than $1 \%$. Japan's total road transport energy consumption (69 million tonnes of oil equivalent) was higher due to its larger population.

China's rapid economic development has seen its annual road transport energy consumption grow from 6.5 million tonnes of oil equivalent in 1973 to 150 million tonnes of oil equivalent in 2010 (an annual average growth rate of $8.9 \%$ ). Other BRICS countries such as India and Brazil have also shown rapid growth in road transport energy use. From 1973 to 2010, road transport energy consumption in India increased from 5.7 million tonnes of oil equivalent to 48.8 million tonnes of oil 
equivalent, an average growth rate of $6.0 \%$ per annum. South Africa's use of energy in road transport increased from 6.4 million tonnes of oil equivalent to 12.0 million tonnes of oil equivalent, an average annual growth rate of $3.7 \%$.

In terms of road transport energy consumption per unit land area, Japan ranks first, using 211 tonnes of oil equivalent/km² in 2010 (IEA, 2012; World Bank, 2014; and authors' calculation). The UK, Germany, and Italy also have relatively high values $\left(171,152\right.$, and 131 tonnes of oil equivalent $/ \mathrm{km}^{2}$, respectively). The (less densely-populated) US and Canada consume only 63.8 and 6.5 tonnes of oil equivalent $/ \mathrm{km}^{2}$ respectively. For BRICS countries, the values are far less than for G7 countries (other than Canada). The per unit land area road transport energy consumption for China and India are both 18.7 tonnes of oil equivalent $/ \mathrm{km}^{2}$; South Africa, Brazil and Russia consume 10.9, 8.3, and 5.9 tonnes of oil equivalent $/ \mathrm{km}^{2}$ respectively.

\subsection{Road transport is gradually becoming the main oil consumer in all countries}

The road transport share of total final oil consumption has increased, both globally and in our countries of focus (Figure 4). This share is particularly high in G7 countries, where more oil is consumed in road transport than in all other final-consuming sectors combined (except Japan). Among BRICS countries, this share is also high in South Africa, Brazil and Russia. China and India currently use a relatively large share of their (final-use) oil in their industrial sectors, but are most likely on track to a similar 
situation of road-transport sector dominance in national final oil demand. In the long run this situation may change, but historical trends are clearly towards a growing share of oil being used in road transport (Keshavarzian, 2012; Wang, 2014). The trend is partly a function of falling use of oil in some other sectors, such as electricity (Burke, 2010).

Figure 4 The proportion of road transport oil consumption in final oil consumption in 1973, 1990, and 2010

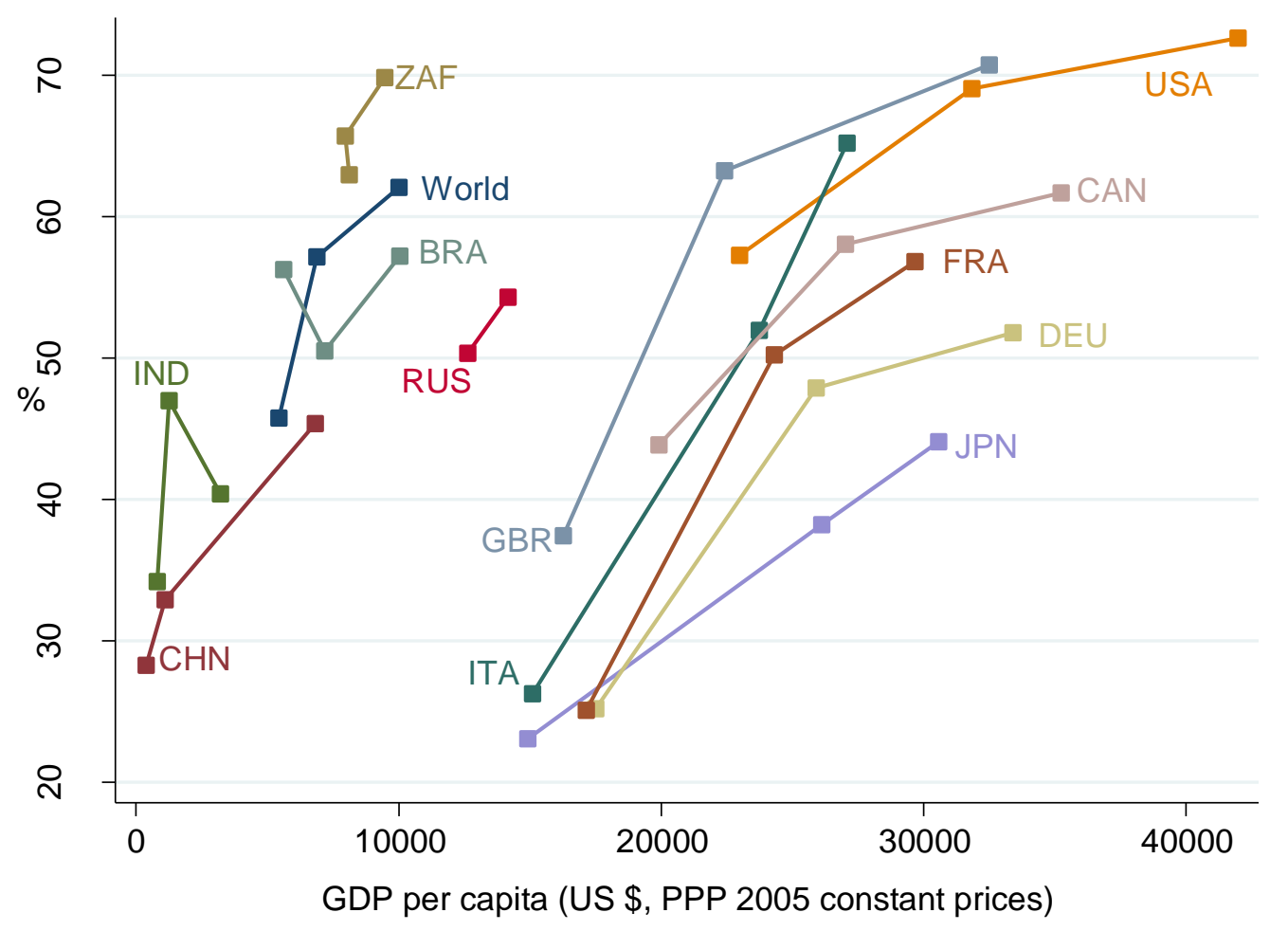

Note: Oil is also used in some energy transformation processes, such as the generation of electricity. This oil is not included in "final consumption"; it is instead part of the broader concept named "primary consumption". Data are not available for Russia in 1973. 
3.4 Per capita road transport energy consumption versus per capita GDP: A longitudinal perspective

Over time, per capita road transport energy consumption has generally been positively correlated with per capita GDP (Figure 5). In G7 economies, however, there has been some lessening in the extent to which per capita road transport energy consumption increases with per capita GDP as the road transport sector has matured. The GDP per capita at which per capita road transport energy consumption has reached a local peak has differed across countries: this level was around $\$ 25,000$ and $\$ 23,000$ in the US and Canada (2005 constant prices, PPP, and similarly hereinafter), while in the EU countries and Japan it was about $\$ 30,000$. Per capita road transport energy consumption has in some instances (e.g. US, Canada) since begun to increase again, although the US again experienced declines during its economic recession in the final years of the sample period. It is too early to conclude that these countries are near "peak energy use in the road transport sector". Figure 4 also shows that road transport energy use can show short-run declines, especially during recessions and/or times of high oil prices.

From 1973 to 2010, the per capita road transport energy consumption of China and India increased at average annual rates of $8 \%$ and $4 \%$ respectively. Due to the social and economic impacts of collapse of the Soviet Union in 1991, Russia firstly saw a decrease, and then rapid growth, in per capita GDP and per capita road transport energy consumption during the period from 1990 to 2010. The per capita GDP and 
per capita road transport energy consumption of South Africa did not show an increasing trend until 1994 (attributable to historical reasons related to the end of apartheid). It can be seen from Figure 5 that very large increases in BRICS' road transport energy use will occur if they are to follow the path of G7 countries.

Figure 5 Per capita road transport energy consumption versus per capita GDP,

$1971-2010$

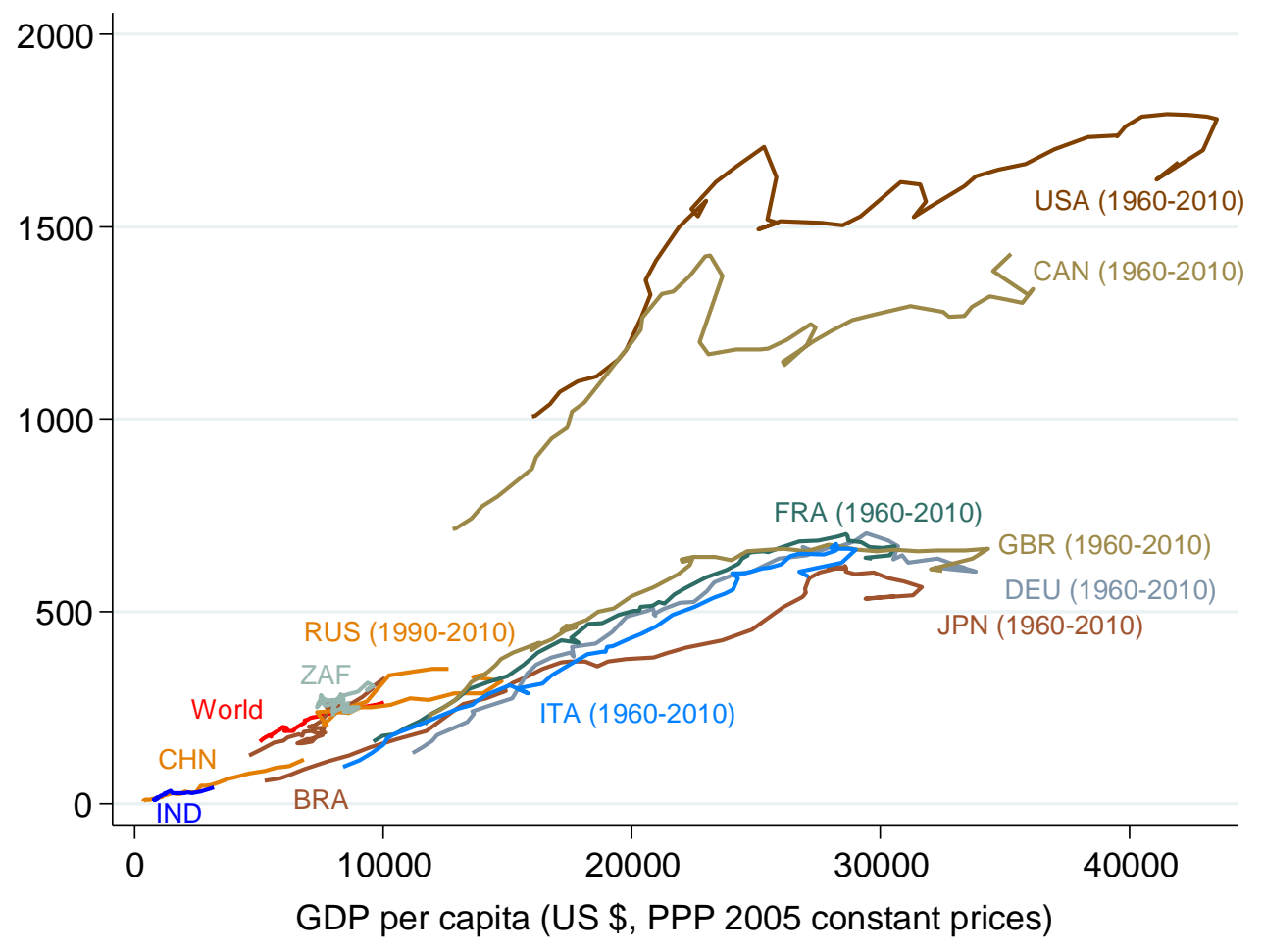

Note: GDP is from IEA (2012). kgoe is "kilogrammes of oil equivalent".

Table 1 lists the elasticity of per capita road transport energy consumption to per capita GDP for each country for three time periods from 1960 to 2010.1973 is used as a break because of the Arab-Israeli war and oil price shock of 1973. 1990 is used as a break for two reasons: 1) the data for Russia start from 1990; 2) the Gulf War broke 
out in 1990 and the Soviet Union collapsed in 1991, which both had implications for the global economy and energy markets. The road transport energy: income elasticity of the G7 countries exceeded 1.0 in the period before 1973 and in some instances exceeded 2.0. Rapid economic development of these countries was associated with even more rapid increases in road transport energy use.

Table 1 Elasticity of per capita road transport energy consumption to per capita GDP (1960-2010)

\begin{tabular}{|c|c|c|c|c|c|c|c|c|c|c|c|c|}
\hline & USA & CAN & GBR & FRA & DEU & ITA & JPN & BRA & RUS & ZAF & CHN & IND \\
\hline $1960-1973$ & 1.2 & 1.2 & 2.2 & 1.7 & 2.5 & 2.0 & 1.6 & - & - & - & - & - \\
\hline $1973-1990$ & 0.0 & 0.0 & 1.3 & 1.1 & 1.2 & 1.3 & 1.0 & 0.8 & - & -0.4 & 0.8 & 2.3 \\
\hline $1990-2010$ & 0.2 & 0.7 & -0.1 & 0.1 & -0.1 & 0.6 & 0.3 & 1.5 & -0.3 & 0.6 & 1.0 & 0.5 \\
\hline
\end{tabular}

Note: We used the straightforward approach of using the ratio of the two average growth rates for the specific periods. Because we have not controlled for prices and other variables, these elasticities are for illustrative purposes and represent general associations.

From 1973 to 1990, this elasticity reduced in all G7 countries. The road transport energy: income elasticities of the US and Canada were close to zero during 1973-1990, while those of the other countries were $c$. 1.0, suggesting a degree of decoupling of road transport energy growth from growth in economic activity.

After 1990, owing to changes in the means by which economic growth was 
manifested, this elasticity was lower than 1.0 (even negative) in G7 countries. The road transport energy: income elasticities of China and Brazil were below 1.0 before 1990; after 1990, as structural change drove robust growth of road transport, they were 1.0 or higher.

\subsection{Explanations of differences between countries}

The per capita road transport energy consumptions of the US and Canada were about 1.5 tonnes of oil equivalent in 2010 , vastly higher than those of the other countries. Per capita road transport energy consumption in the EU countries and Japan was about 0.6 tonnes of oil equivalent. Brazil, China, and India had per capita road transport energy consumptions of $0.3,0.1$, and 0.04 tonnes of oil equivalent, respectively. The sizeable differences between countries are largely driven by the stage of development; countries with high per capita GDP tend to have higher per capita road transport energy consumption. Per capita road transport energy consumption also varies due to factors such as relative resource abundance, vehicle ownership levels, consumption habits, pricing and other policies, and infrastructure availability (Liu et al., 2006; Burke and Nishitateno, 2013).

As might be expected, ownership of four-wheeled motor vehicles is closely associated with per capita road transport energy consumption. Figure 6 shows the relationship between ownership of these vehicles per thousand people and per capita road transport energy consumption for an expanded sample of 84 countries in 2008. The 
size of the bubbles reflects total vehicle ownership in each country. Naturally enough, higher vehicle ownership levels are associated with higher per capita road transport energy consumption. In 2010, four-wheeled motor vehicle ownership per thousand people exceeded 600 in Canada, France, Italy, and Japan: in the US, it exceeded 800. In contrast, four-wheeled motor vehicle ownership per thousand people is much lower in BRICS countries (e.g. China and India: 37 and 17, respectively) (IRF, 2012).

Figure 6 Four-wheeled motor vehicle ownership per thousand people versus per capita road transport energy consumption in 2008

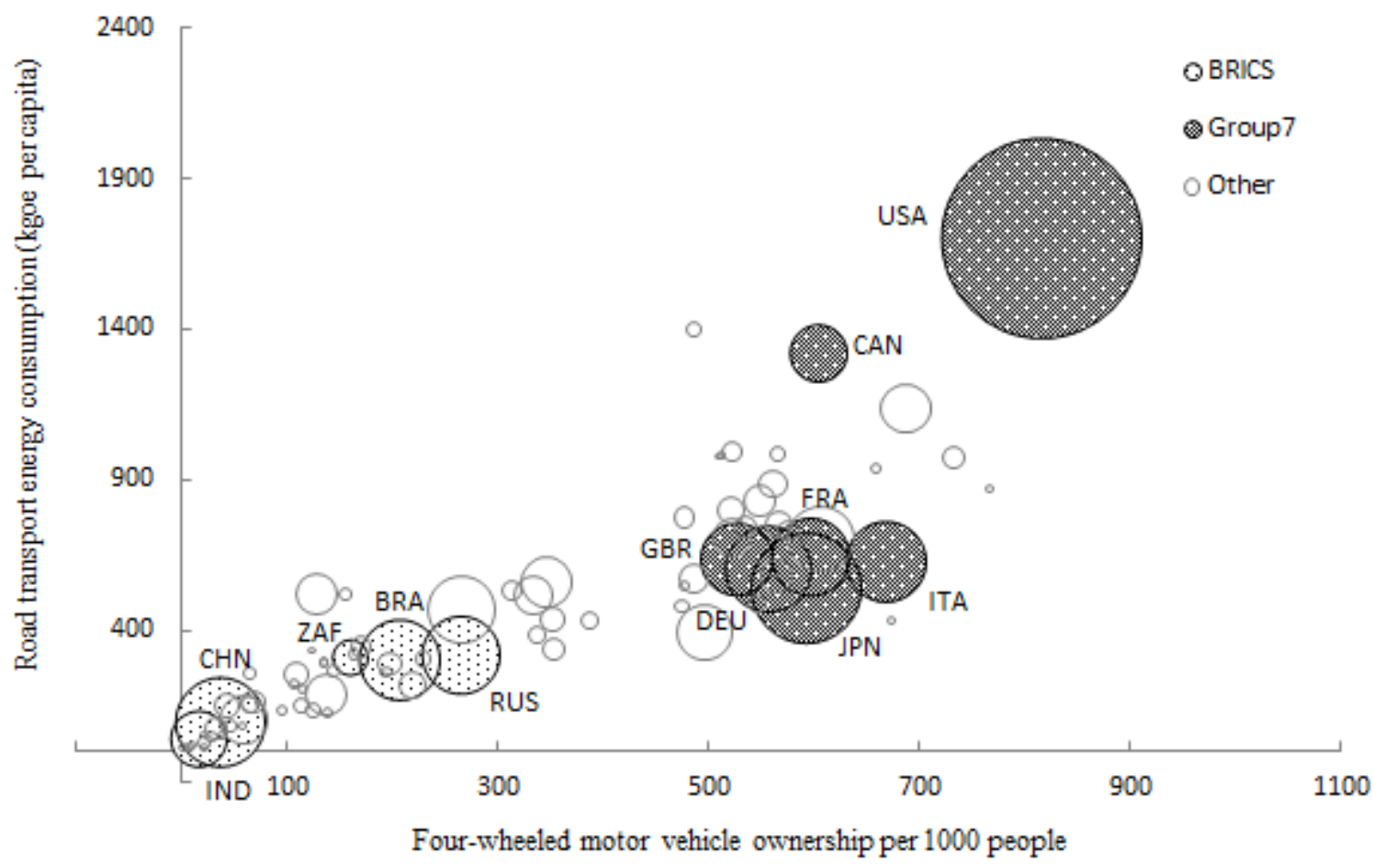

Note: The area of each bubble is proportional to total four-wheeled motor vehicle ownership.

Four-wheeled motor vehicle ownership is from the IRF (2012). 84 countries are included.

The number of high energy-consuming vehicles, such as sports utility vehicles, light 
vans, and light trucks has grown rapidly in the US (Du et al., 2013). This is a key reason why the per capita road transport energy consumption of the US is higher than in other countries. A recent documentation of how vehicle ownership evolves as economies develop is provided by Nishitateno and Burke (2014).

Resource endowments also appear to influence per capita road transport energy consumption. The US and Canada are rich in fossil fuel resources: by the end of 2010, their proven crude oil reserves were 2.5 and 28.2 billion tonnes, respectively (U.S. EIA, 2012). Perhaps partly because of their relatively abundant energy supplies, among other reasons, the US and Canada have lower fuel tax rates, meaning their fuel prices are relatively low and their consumption is high (Burke and Nishitateno, 2013). France, Germany, and Italy are lacking in fossil fuel resources: by the end of 2010, their proven crude oil reserves were 10 million, 40 million, and 60 million tonnes respectively (U.S. EIA, 2012). Fossil fuel reserves are extremely deficient in Japan, with proven crude oil reserves of only 6 million tonnes in 2010 (U.S. EIA, 2012). These resource-limited countries have had higher fuel taxes and implemented generally tighter energy-saving measures (Burke and Nishitateno, 2013). Nevertheless, almost all countries have adopted some policies to promote the development of public transport and/or encourage the use of fuel-efficient and/or clean-energy vehicles in an attempt to improve energy efficiency (Wei et al., 2010).

As shown in Figure 7, European and Japanese fuel prices are much higher than those 
in the US and Canada. The price differences arise mostly from the different fuel taxes collected by their governments (as well as international transport costs). The high fuel taxes in European countries and Japan reduce road transport energy consumption to some extent, with estimates of the long-run fuel price elasticity of road transport fuel demand typically falling in the range -0.2 to -0.8 (Sterner, 2007; Dahl, 2012; Havranek et al., 2012; Burke and Nishitateno, 2013). There is also evidence that the effects of gasoline prices flow through to other road-sector outcomes, such as the number of road deaths: countries with higher gasoline prices tend to have fewer road fatalities, holding other factors constant (Burke and Nishitateno, In press).

Figure 7 Gasoline and diesel prices in 2010

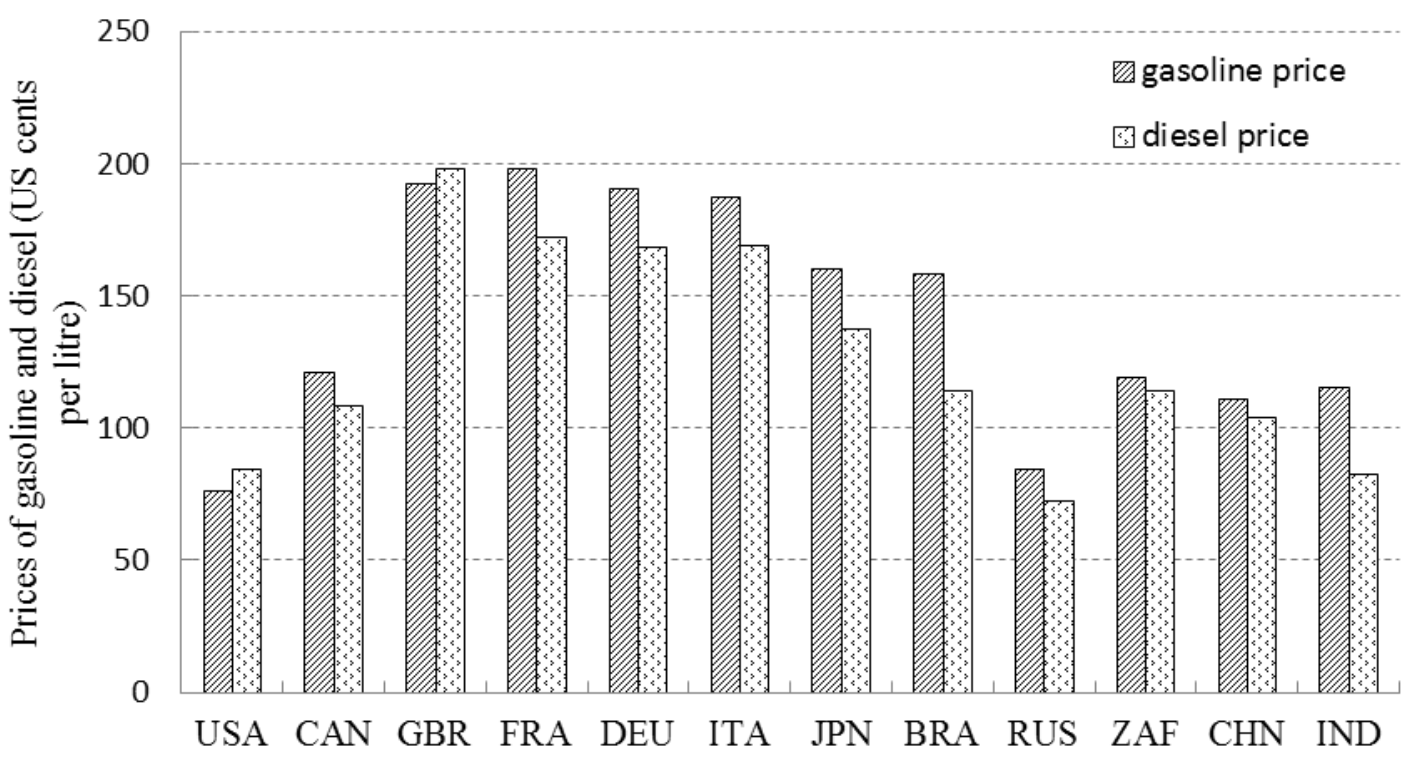

Source: World Bank (2014).

Infrastructure availability is also an important factor influencing road transport energy consumption. As shown in Figure 8, per capita road transport energy consumption is 
positively related to per capita road distance across an expanded sample of 78 countries in 2010. The road networks of Canada and the US stretched 29.4 and 21.1 metres per capita respectively in 2010, far longer than other G7 or BRICS countries due to their large land areas, high levels of economic development, and road-prioritising transport development histories. China's road distance per capita was only 3.0 metres in 2010 (up from 0.02 metres in 1975). The road distance per capita was 3.74 in India in 2010 (up from 2.0 metres in 1973).

Figure 8 Road distance per capita versus per capita road transport energy consumption in 2010

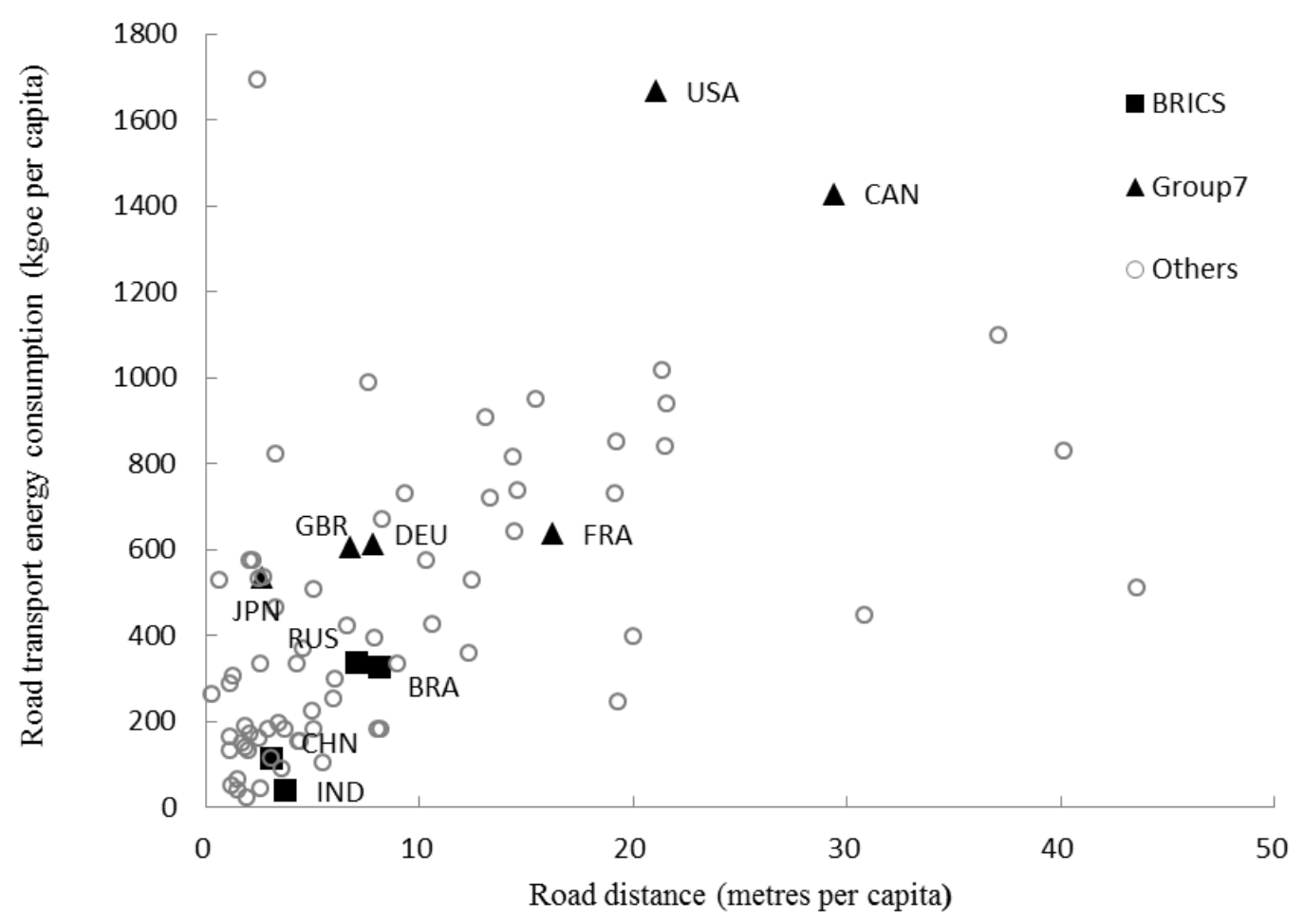

Note: Data are not available for Italy and South Africa. Road distance data are from World Bank (2014).

78 countries are included. 


\section{Structural changes in road transport energy}

\subsection{Oil is still dominant, but its share in road transport energy is declining}

In 1973, the oil share of road transport energy consumption exceeded $99 \%$ in the 12 countries we are studying. By 2010 this share had reduced in most countries, although Japan and South Africa had shown little change. In Brazil, the oil share of road transport energy consumption had fallen to only $75 \%$ in 2010 . The fall in this share was mostly as a result of policies to encourage the substitution of oil with biomass energy: by 2010, Brazil's biomass energy share in road transport reached $22 \%$. Biomass energy utilisation also increased in France, Italy, and the US, to 5.9\%, 4.1\%, and $4.7 \%$ respectively. Use of natural gas also increased, with the natural gas utilisation ratios of China and India both rising from zero in 1973 to $4.7 \%$ in 2010 .

Given the pressures on the environment and on fossil fuel resources in general, the proportion of clean energy in final energy consumption will likely increase in the future (Liao and Wei, 2010). A number of countries have adopted policies that promote the uptake of clean energy sources, such as fuel taxes, subsidies for biomass, fuel economy standards, and tax incentives to purchase electric cars. As a result of these policies, pressure from rising oil prices, and ongoing technical progress, the vehicle fuel efficiency ratings of new vehicles have generally been improving in almost all countries (Cuenot and Körner, 2013).

Sales of electric vehicles (EVs) and non-plug-in hybrid-electric vehicles (HEVs) grew 
strongly in 2011 and 2012, but their market shares are still small (IEA, 2013). For example, in 2012, HEVs only made up $1.5 \%$ of global new-vehicle sales (IEA, 2013). This may well change over the next decade or two. Currently, however, gasoline and diesel generally remain cheaper road transport options than the alternatives. While alternative technologies are improving quickly, ongoing improvements in the fuel economy of gasoline- and diesel-powered vehicles make the task of achieving mass sales of alternative technologies (e.g. EVs) more challenging.

Most affordable EVs still do not run far without being recharged, although advances are ongoing. There is a need for a roll-out of more charging facilities to see broader uptake. Given the challenges associated with alternative energy sources, oil will likely keep its dominant position in most countries in the medium term. In the long run, however, pollution concerns and resource constraints mean it is likely that alternative technologies such as EVs will come to dominate the market (Huo et al., 2012; He and Chen, 2013). If their costs continue to decrease, in the long run a mass transition to non-oil powered vehicles appears inevitable.

\subsection{The rise of diesel}

The main oil products used in road transport are gasoline and diesel. As shown in Figure 9, the relative importance of diesel and gasoline varies. The proportion of diesel consumption increased in all the countries due to the increasing popularity of diesel vehicles given their higher energy efficiency and the lower taxes on diesel fuel 
in most countries (Harding, 2014). Some countries, particularly in Europe, have also had policies to encourage the use of diesel vehicles (Wallington et al., 2013).

Figure 9 Energy sources used in road transport

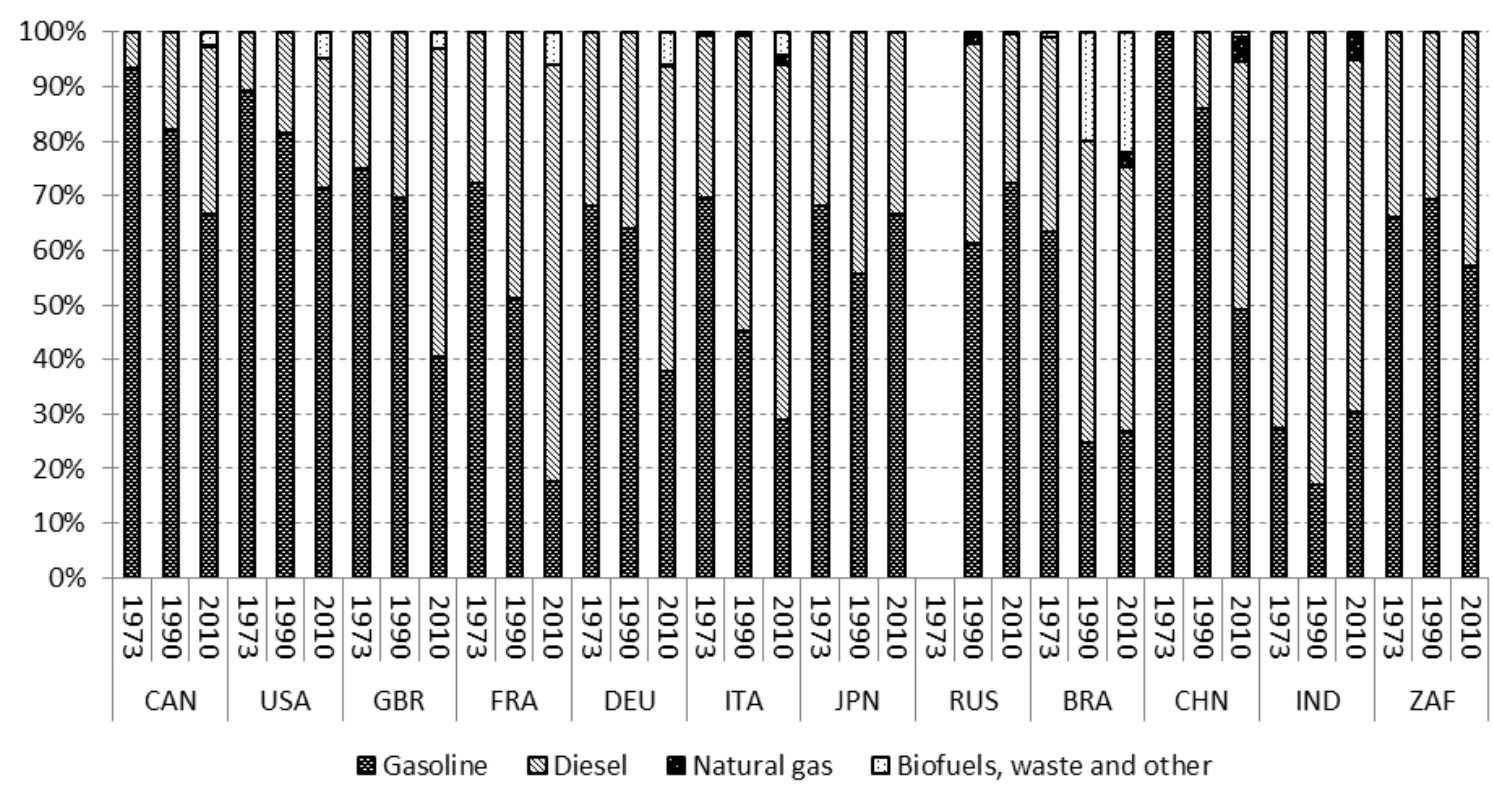

In 1973, gasoline consumption in the road sector exceeded diesel consumption in all the countries in our sample except India. By 2010 the proportion of diesel consumption had increased (also except in India). In the UK, France, Germany, and Italy, diesel is now the main road transport fuel. From 1973 to 2010, China's use of diesel for road transport increased significantly due to rapid growth in freight transport. Gasoline and diesel now rank as equally important as road transport fuel sources in China. 


\section{Conclusions}

Transport is a key energy consuming sector, and road transport is the major part thereof. With continued increases in income levels, in most countries the shares of transport energy in total final energy consumption and of the road transport sector in transport energy consumption will likely continue to increase for some years to come.

The per capita road transport energy consumptions of different countries vary widely, with the US and Canada far exceeding the other G7 countries. In addition to economic development, per capita road transport energy consumption is affected by factors such as fuel tax policies, the abundance of resources, road infrastructure, and residential consumption habits (e.g. vehicle ownership decisions). For a variety of reasons, road transport energy consumption growth is in a decelerating phase in developed countries. It is far from clear that these countries are near "peak energy use in the road transport sector", however.

Oil has been the main source of road transport energy. This situation may persist in the medium term, despite advances in alternative technologies such as electric cars. The proportion of diesel consumption is increasing. The market share of clean, renewable energies in road transport energy remains small, but they are likely to play a larger role in the future (perhaps via clean electricity generation). The extent to which EVs and HEVs will help to reduce emissions depends partly on the uptake of low-carbon generation sources in the electricity sector, the prospects for which are 
generally improving (Cong, 2013; Cong and Shen, 2014).

As a rapidly developing country, China's road sector has been expanding quickly due to urbanisation, infrastructural improvement, and increasing personal incomes. Oil will likely be China's main source of road transport energy consumption for some years to come, although pollution and resource considerations suggest that it would perhaps be sensible for China to not follow the development paths of the US or Canada when it comes to road transport energy use. Fortunately vehicle fuel economy and alternative vehicle technologies are improving, and there are numerous policy options available for reducing negative externalities from the road transport sector. These include externality pricing of emissions and congestion (Burke, In press), public transport initiatives, support for research into and adoption of new-energy vehicles, and vehicle energy efficiency initiatives. China has already implemented policies of sizeable ambition, including new-vehicle fuel economy standards, rail investments, and programs for the adoption of EVs (Gong et al., 2013).

\section{Acknowledgements}

We are thankful for financial support from the "Strategic Priority Research Program" of the Chinese Academy of Sciences (No. XDA05150600), National Natural Science Foundation of China (No. 71322306, 71273027, and 71020107026), and Program for New Century Excellent Talents in University of Ministry of Education of China (No. NCET-13-0040). 


\section{References}

Burke, P. (In press) 'Green pricing in the Asia Pacific: An idea whose time has come?', Asia \& the Pacific Policy Studies, DOI: 10.1002/app5.39.

Burke, P. (2010) 'Income, resources, and electricity mix', Energy Economics, Vol. 32, No. 3, pp. 616-626.

Burke, P. J. and Nishitateno, S. (In press) 'Gasoline prices and road fatalities: International evidence', Economic Inquiry.

Burke, P. J. and Nishitateno, S. (2013) 'Gasoline prices, gasoline consumption, and new-vehicle fuel economy: Evidence for a large sample of countries', Energy Economics, Vol. 36, pp. 363-370.

Cong, R. G. (2013) 'An optimization model for renewable energy generation and its application in China: a perspective of maximum utilization'. Renewable and Sustainable Energy Reviews, Vol. 17, pp. 94-103.

Cong, R. G., \& Shen, S. (2014). 'How to Develop Renewable Power in China? A Cost-Effective Perspective'. Scientific World Journal, Vol. 2014.

Cuenot, F. and Körner, A. (2013) 'International comparison of light-duty vehicle fuel economy: An update using 2010 and 2011 new registration data', Working Paper 8, Global Fuel Economy Initiative. 
Dahl, C. A. (2012). 'Measuring global gasoline and diesel price and income elasticities'. Energy Policy, Vol. 41, pp. 2-13.

Du, X. W., Liu, X. L., Yang, B., Wang, Z. H. and Kang, J. C. (2013) 'An international comparative study on the scope of China's energy development', Chinese Academy of Engineering, Vol. 6, pp. 4-10. (in Chinese)

Gong, H. M., Wang, M. Q., Wang, H. W. (2013) 'New energy vehicles in China: policies, demonstration, and progress', Mitigation and Adaptation Strategies for Global Change, Vol. 18, pp. 207-228.

Harding, M. (2014) The Diesel Differential: Differences in the Tax Treatment of Gasoline and Diesel for Road Use (No. 21), OECD Publishing.

Havranek, T., Irsova, Z., \& Janda, K. (2012) 'Demand for gasoline is more price-inelastic than commonly thought'. Energy Economics, Vol. 34, No. 1, pp. 201-207.

He, L. Y., \& Chen, Y. (2013) 'Thou shalt drive electric and hybrid vehicles: Scenario analysis on energy saving and emission mitigation for road transportation sector in China', Transport Policy, Vol. 25, pp. 30-40.

Huo, H., Wang, M., Zhang, X. L., He, K. B., Gong, H. M., Jiang, K. J., Jin, Y. F., Shi, Y. D. \& Yu, X. (2012) 'Projection of energy use and greenhouse gas emissions by motor vehicles in China: Policy options and impacts', Energy Policy, Vol. 43, 
pp. 37-48.

International Energy Agency (2012) World Energy Statistics and Balances 2012, International Energy Agency, Paris.

International Energy Agency (2013) Tracking Clean Energy Progress 2013, International Energy Agency, Paris.

International Road Federation (2012) World Road Statistics, International Road Federation, Geneva. Data from earlier volumes also utilised.

Keshavarzian, M., Kamali Anaraki, S., Zamani, M., \& Erfanifard, A. (2012) 'Projections of oil demand in road transportation sector on the basis of vehicle ownership projections, worldwide: 1972-2020', Economic Modelling, Vol. 29, No. 5, pp. 1979-1985.

Liao, H. and Wei, Y.M. (2010) 'Characteristics of energy structural change in Group 7 and BRICS', Energy of China, Vol. 2, pp. 22-25 + 46. (in Chinese)

Liu, S.J. et al. (2006) Between Tradition and Modern: Transformation of Growth Pattern and Choice for New Industrialisation, China Renmin University Press, Beijing. (in Chinese)

Nishitateno, S. and Burke, P.J. (2014) 'The motorcycle Kuznets curve', Journal of Transport Geography, Vol. 36, pp. 116-123. 
Sterner, T. (2007) 'Fuel taxes: An important instrument for climate policy', Energy Policy, Vol. 35, No. 6, pp. 3194-3202.

U.S. Energy Information Administration (2012) International Energy Statistics 2012, available at http://www.eia.gov/cfapps/ipdbproject/IEDIndex3.cfm (accessed 6 February 2014).

Wallington, T. J., Lambert, C. K. and Ruona, W. C. (2013). 'Diesel vehicles and sustainable mobility in the US', Energy Policy, Vol. 54, pp. 47-53.

Wang, Y. F., Li, K. P., Xu, X. M., \& Zhang, Y. R. (2014) 'Transport energy consumption and saving in China', Renewable and Sustainable Energy Reviews, Vol. 29, pp. 641-655.

Wei, Y.M., Liao, H. et al. (2010) China Energy Report: Energy Efficiency, Science Press, Beijing. (in Chinese)

World Bank (2014) World Development Indicators 2014, World Bank, Washington DC. 